\title{
The Impact of Participation in Service Company's Socially Responsible Activities on Employee's Affective Commitment
}

Milena Damnjanović

Faculty of Technical Sciences Čačak, University of Kragujevac, Serbia

\begin{abstract}
Employees' perspectives of the company's social responsibility (SR) and the company's SR impact on employees have so far been given little attention in research. This gap is surprising since it is well known to what extent employees affect overall companies' results. They have a crucial role in SR activities implementation, so it is important for management to define employees' roles in SR activities implementation carefully. This paper explored the influence of employees' participation in SR activities on their affective commitment to service companies. The main hypothesis was that participation in SR activities has a significant positive impact on employees' affective commitment. The goal was to show that employees who participated in SR activities were more committed than employees who did not participate in SR activities. The data were collected through a questionnaire and analysed using descriptive statistics, independent-samples t-tests, and one-way ANOVA. The results showed that there were no statistically significant differences in the level of affective commitment between employees who participated in SR activities and those who did not participate in them. Less than half of respondents participated in SR activities, so a suggestion for managers was to share the positive experience of participation in SR activities and invite employees to participate more.
\end{abstract}

Keywords: employees, social responsibility, affective commitment JEL classification: M14, M51, M54

Paper type: Research article

Received: Feb 24, 2021

Accepted: May 4, 2021

DOI: 10.54820/RPPI2505 


\section{Introduction}

In the last decade, a growing interest in social responsibility (SR) practices in the service industry and their effects have been noticed, and significant research has been done in this field. Some studies investigated the relationship between SR and financial performances; others were micro-CSR studies, which investigated the relationship between SR and employees, customers, local community. Employees perceptions about SR and the impact of SR participation on employees in the service industry is still under-researched field (Nazir et al., 2021; Bogan et al., 2020; Wang et al., 2020; Kim et al., 2020; Hu et al., 2019; Su et al., 2019; Youn et al., 2018), especially in developing countries (Bogan et al., 2020; Wang et al., 2020; Yasir et al., 2020). Employees have direct contact with customers in the service industry, and their attitudes and behaviors are highly critical for reaching business goals. A better understanding of SR's effects on employees' well-being should be important for this industry.

In general, prior research in the service industry indicates that a company's SR activities can increase customers' trust and satisfaction, repurchase and revisit intentions, financial performance, employees' green behavior, and positive work outcomes by service employees (Jeon et al., 2020; Su et al., 2019). Some research showed a positive relationship between employees' SR participation and various employee outcomes, but results in the service industry context are still unclear (Hu et al., 2019).

The subject of this paper was the influence of employees' participation in SR activities on their affective commitment to Serbian service companies. Service companies were chosen due to the specific nature of service "production". SR activities need to be implemented with the help of employees as that way those activities will be more valuable for employees and could enhance their commitment. Committed employees provide better service, so the aim was to show a statistically significant difference in the level of affective commitment between employees who participated in SR activities and those who did not.

This research contributed to the existing literature by focusing on the link between employees' outcomes and SR. There is a lack of SR studies focusing on employees, especially in the service industry. Investigating how employees perceive and respond to a company's SR initiatives is also meaningful for companies to achieve a competitive advantage in the market. These findings could be applied to the development of potential SR strategies/activities for service companies. Another contribution of this paper is that the research was done in the service industry in a developing country, and research about the relations between SR and employee outcomes is still rare in developing countries.

\section{Literature review}

\section{Social responsibility in the service industry}

The service industry has a growing significance in the world economy, as it creates large revenues, has an important role in income creation, and contributes to employment increase. The service sector contributes to more than $80 \%$ of GDP and employs more than $70 \%$ of people in the world's most developed countries. In Serbia, the service sector contributed to creating GDP with 51,2\% in 2019 (Privredna komora Srbije, 2020), and that share was above 50\% for the last five years. According to the data from the third quartal in 2019, the biggest number of employees in Serbia was in the service sector $(57,4 \%)$, then in the industry $(22,4 \%)$ and agriculture $(15,3 \%)$ 
(Republika Srbija Republički zavod za statistiku, 2020), and the similar results were in the year before.

It is well known that employees are one of the most important stakeholders for any company. Employees can be influenced by, but also they can influence different organizational activities, so they have a key role in achieving organizational effectiveness. They directly determine if the company will experience success or failure in the market. Employees are expected to have opinions about companies' SR activities, and those opinions always influence their level of support and participation in SR activities. A service company'S SR activities positively impact a firm's performance higher than a manufacturing company's (Jeon et al., 2020).

Employees' SR participation usually occurs in the form of corporate volunteer programs in which employees invest their time and skills in service to the community (Im et al., 2016, Hu et al., 2019). SR participation is also defined as the degree to which they are involved in social and environmental activities in their actions and policies at various levels of the organization (Yasir et al., 2020).

Companies are dependent on employee responsiveness to and participation in $S R$ for the effective delivery of SR activities. SR participation can be a powerful experience for employees to become aware of their organization's desired behavior.

Employee participation in SR activities is important for several reasons (Nazir et al., 2021; Hu et al., 2019; Chen et al., 2014). Their participation can make SR a part of the organizations' actions which came from its culture or values, and not as something forced from the outsiders. Then, SR practices are becoming long-term behavioral changes of all companies' stakeholders. Employees feel a sense of pride and identification with the company. When employees participate in SR initiatives, they develop and foster their specific skills, which can help them advance their careers. Involvement and participation in SR activities help employees satisfy their need for autonomy by pursuing and solving social issues and making a difference with a sense of ownership. Participation in SR activities leads to improved employee morale, self-development, job satisfaction, identification with the company, organizational citizenship behaviors, commitment and emotional attachment, quality of working life, and overall quality of life (Jeon et al., 2020; Hu et al., 2019; Chen et al., 2014). SR context nourishes and enriches an employee's desire to impact the broader world as a significant motivational context for employees. Participation in SR activities provides a broadened social awareness of the individual's situation in the world, in contrast to the flattened awareness associated with a purely instrumental orientation towards the society that stunts meaningfulness (Nazir et al., 2021).

Participation in SR activities impacts employee-focused outcomes in the service industry is still unclear and demands researchers' attention (Hu et al., 2019).

\section{Affective commitment}

Commitment is one of the essential factors of the long-term relationships between an organization and its employees. Various definitions of commitment have been given over the years. For this paper, the explanation of Meyer et al. (1997) was accepted. They explained commitment from three points of view. Firstly, commitment has been viewed as reflecting an affective orientation toward the organization, recognition of costs associated with leaving the organization, and finally, as a moral obligation to remain with the organization. That way, they proposed a three-component model of organizational commitment: affective, continuance, and normative commitment (Meyer et al., 1997). Affective commitment refers to the employee's emotional attachment to, identification with, and involvement in the organization (Meyer et al., 
1997). Employee wants to stay in the organization. Continuance commitment refers to an awareness of the costs associated with leaving the organization (Meyer et al., 1997). Employees need to stay in the organization. Normative commitment reflects a feeling of obligation to continue employment (Meyer et al., 1997). Employees ought to stay in the organization. The literature suggests that an affective commitment has the strongest and positive correlation with organizational and employee-relevant outcomes (Youn et al., 2018). For this paper, an affective commitment was measured, and the link between SR participation of employees and affective commitment was tested.

The strongly committed employee identifies with, is involved in, and enjoys membership in the organization (Im et al., 2016). Literature generally supports a positive relationship between SR participation and affective commitment (Wang et al., 2020; Khaskheli et al., 2020; Youn et al., 2018; Im et al., 2016), but there is not a lot of research in the service industry. Some research in the hospitality setting showed that organizational commitment strongly influences the quality of guest services (Youn et al., 2018). Let's take into consideration the importance of employee attitudes and behaviors in the service industry. Service industry companies should invest significantly in SR activities to get positive reactions from employees. SR practices could provide a strategic competitive advantage in the long term. By carrying out SR initiatives that increase the quality of life in local communities where they operate, service industry companies could ensure employees' commitment.

\section{Methodology}

This paper explored the influence of employees' participation in SR activities on their affective commitment to the Serbian service industry. The main hypothesis was that participation in SR activities has a significant positive impact on employees' affective commitment. The goal was to show that employees who participated in SR activities were more committed than employees who did not participate in SR activities. Also, additional goals were to show that the majority of employees participated in SR activities. Then, there were differences between employees of different ages, sex, educational background, work experience, and position within the company in the level of participation in SR activities. Respondents were asked to give examples of SR activities they participated in, so the most common activities could be identified. The data were collected through a questionnaire, which was distributed online. The research was conducted in January and February 2021. The focus was on the service industry. The questionnaire, which was used in data collection, consisted of three parts. The first part of the questionnaire included basic questions about respondents (sex, age, education, work experience, position in company). In the second part of the questionnaire, respondents were asked if they had participated in SR activities within the company and gave some examples. The third part of the questionnaire referred to affective commitment. The affective commitment was measured using Meyer et al. (1997) Affective Commitment Scale, as this is the most used scale in similar research for measuring affective commitment. Data were analyzed using descriptive statistics, independent-samples t-test, and one-way ANOVA.

The sample counts 100 respondents from various service companies in Serbia. Almost 1.000 questionnaires were distributed, 100 answers came back, so the response rate was about $10 \%$. The structure of respondents who participated in this research using different criteria is given in Table 1. 
Table 1

The structure of respondents

\begin{tabular}{llc}
\hline Variable & Modalities & $\%$ \\
\hline Sex & Male & 30 \\
Age & Female & 70 \\
& $20-30$ & 20 \\
& $31-40$ & 42 \\
& $41-50$ & 20 \\
Degree of vocational & $51-60$ & 15 \\
education & Secondary school qualifications & 3 \\
& Two-year post-secondary school & 16 \\
& qualifications & 15 \\
& Bachelor & 31 \\
& Master of Science & 33 \\
Work experience & Magister & 3 \\
& PhD & 2 \\
& $1-5$ years & 34 \\
Position in company & $6-10$ years & 16 \\
& $11-15$ years & 27 \\
& $>16$ years & 23 \\
\hline Source: Authogerial position & 55 \\
& Non-managerial position & 45 \\
\hline
\end{tabular}

Source: Authors' work

\section{Results}

Employees gave answers to the question if they have participated in SR activities of their company. There were $10 \%$ of employees who were uninterested in participating in such activities, $41 \%$ never participated, and $49 \%$ participated in SR activities regularly. More than half of the respondents did not participate in SR activities. Employees gave different examples of SR activities in which they participated. The biggest attention was given to helping children in different ways, then to the environment preservation. It was interesting to note that improving working conditions and care for employees were not listed as priority areas. The examples of the most common SR activities in service companies are given in Table 2.

Table 2.

The most common SR activities in service companies

\begin{tabular}{lc}
\hline SR activity example & $\%$ \\
\hline $\begin{array}{l}\text { Children from marginalized groups (New years' gifts donation, donations, } \\
\text { education) }\end{array}$ & $16 \%$ \\
Preservation of the environment (planting trees, landfill cleaning, recycling, & $15 \%$ \\
children education, arranging the schoolyards) & $2 \%$ \\
Giving food for a public kitchen & $2 \%$ \\
Work condition improvement & $2 \%$ \\
Voluntary blood donation &
\end{tabular}

Source: Authors' work

Participation in SR activities was mostly reserved for managerial staff, as $33 \%$ of them participated in SR activities compared to $16 \%$ of non-managerial staff. Most women participated in SR activities (32\%), while $17 \%$ of men participated in SR activities. Almost $40 \%$ of employees younger than 40 did not participate in SR, while $26 \%$ of employees older than 40 regularly participated. Employees with $6-10$ and 
more than 16 years of work experience mostly participated in SR activities (27\%), but $39 \%$ of employees with $1-5$ and $11-15$ years of experience did not participate in such activities. Considering the degree of vocational education level, the distribution of employees was almost $50 \%-50 \%$ in each group.

One-way ANOVA was done to determine if there were statistically significant differences in the level of affective commitment between employees who participated in SR activities, employees who did not participate in SR activities, and those who were not interested in such participation. Descriptive statistics are presented in Table 3. Levene Statistic was 2.434, at confidence level $p=0.093$, so the assumption of homogeneity of variances was not violated.

Table 3

Level of affective commitment by groups

\begin{tabular}{lccc}
\hline $\begin{array}{l}\text { Participation in SR } \\
\text { activities }\end{array}$ & $\mathrm{n}$ & Mean & $\begin{array}{c}\text { Std. } \\
\text { Dev. }\end{array}$ \\
\hline Yes, regurarly & 49 & 3.8316 & 0.82741 \\
No, never & 41 & 3.3994 & 1.12230 \\
Not interested & 10 & 3.9000 & 0.76784 \\
\hline Total & 100 & 3.6613 & 0.97106 \\
\hline
\end{tabular}

Source: Authors' work

The results of one-way ANOVA are presented in Table 4. The results showed no statistically significant differences between affective commitment in three groups of employees $(\mathrm{F}=2.631, \mathrm{p}=0.077)$.

Table 4

Results of one-way ANOVA

\begin{tabular}{llclll}
\hline & $\begin{array}{l}\text { Sum of } \\
\text { Squares }\end{array}$ & df & $\begin{array}{l}\text { Mean } \\
\text { Square }\end{array}$ & F & Sig. \\
\hline $\begin{array}{l}\text { Between } \\
\text { Groups }\end{array}$ & 4.804 & 2 & 2.402 & 2.631 & $0.077^{*}$ \\
$\begin{array}{l}\text { Within Groups } \\
\text { Total }\end{array}$ & 88.549 & 97 & 0.913 & & \\
\hline
\end{tabular}

Note: * statistically significant at $10 \%$

Source: Authors' work

The differences in the level of affective commitment were tested using an independent-samples t-test. The sample was transformed, so employees who did not participate in SR activities and employees who were not interested in such participation formed one group. This group was compared to the group of employees who participated in SR activities. Descriptive statistics are given in Table 5 .

Table 5

Descriptive statistics for the affective commitment

\begin{tabular}{lllll}
\hline Participation in SR activities & $\mathrm{n}$ & Mean & Std. Dev. & Std. Error Mean \\
\hline Yes, regurarly & 49 & 3.8316 & 0.82741 & 0.11820 \\
No, never and not interested & 51 & 3.4975 & 1.07427 & 0.15043 \\
\hline
\end{tabular}

Source: Authors' work

Levene's test for equality of variances showed that equality of variance should be assumed ( $F=2.914, p=0.091>0,05)$. In Table 6, the t-test result is presented. The results showed that there were no statistically significant differences in the level of affective 
commitment between employees who participated in SR activities (mean=3.8316, standard deviation $=0,82741$ ) and employees who did not participate and were not interested (mean=3.4975, standard deviation=1.07427), $\dagger(98)=1.737, p=0.085$. The mean difference $(0.33408,95 \% \mathrm{Cl}:-0.04753$ to 0.7157$)$ was very small (eta squared $=0.0299$ ).

Table 6

T-test for equality of means of affective commitment

\begin{tabular}{lccccc}
\hline$t$ & df & Sig. (2-tailed) & Mean Difference & $95 \%$ Confidence Interval \\
\hline 1.737 & 98 & $0.085^{*}$ & 0.33408 & $-0.04753 a$ & $0.71570 \mathrm{~b}$ \\
\hline Note: * statistically significant at & 10\%; a-lower $95 \%$ & confidence interval, b-upper 95\% \\
confidence interval \\
Source: Authors' work
\end{tabular}

\section{Conclusion}

Results showed that participation in SR activities does not increase or decrease the affective commitment of employees. In the world pandemic and very hard time for service companies, as they had the most restrictions for doing business in the last year, these results were maybe expected. The share of employees who participated in SR activities was smaller than researchers expected it to be. So more research will be done.

Limitations of this research include sample size, as a bigger sample could allow more generalized and perhaps different conclusions. Also, research should be repeated after some time to determine if there were some changes. Participation of employees was measured only through one item, so for future research new construct for SR activity participation could be developed with several items.

The lack of similar research and the increasing importance of SR in contemporary business motivated this research to examine how SR activity participation influence employees' affective commitment in the service industry context, especially due to the essential role of employees for business success in service industries. The fact that research was done in developing countries and in time of world pandemic also gave its incentive.

Results showed the absence of a statistically significant difference in the level of affective commitment between employees who participated in SR activities and those who did not participate. Half of the employees did not participate in SR activities at all. Most who participated were female, at the managerial position, older than 40 years, with different amounts of working experience. It is always important that managers communicate the outcomes of SR activities, share the positive experience with participation in SR activities, and invite employees to participate. If more employees were participated in SR from different levels in the company, SR activities would be more visible for all employees and could motivate them to participate.

\section{References}

1. Bogan, E., Dedeoglu, B. B. (2020), "Hotel employees' corporate social responsibility perception and organizational citizenship behavior: Perceived external prestige and pride in organization as serial mediators", Corporate Social Responsibility and Environmental Management, Vol. 27 No. 5, pp. 2342-2353.

2. Bogan, E., Turkay, O., Dedeoglu, B. B. (2018), "Perceived corporate social responsibility and job satisfaction: the mediator role of organizational identification", International Journal of Business and Management Studies, Vol. 10 No. 2, pp.51-67. 
3. Chen, Y. R. R., Hung-Baesecke, C. J. F. (2014), "Examining the Internal Aspect of Corporate Social Responsibility (CSR): Leader Behavior and Employee CSR Participation", Communication Research Reports, Vol. 31 No. 2, pp. 210-220.

4. Hu, B., Liu, J., QU, H. (2019), "The employee-focused outcomes of CSR participation: The mediating role of psychological needs satisfaction", Journal of Hospitality and Tourism Management, Vol. 41, pp.129-137.

5. Im, S., Chung, Y. W., Yang, J. Y. (2016), "Employees' Participation in CSR and Organizational Outcomes", Sustainability, Vol. 9 No. 28, pp.1-14.

6. Jeon, M. M., Lee, S., Jeong, M. (2020), "Perceived corporate social responsibility and customers' behaviors in the ridesharing service industry", International Journal of Hospitality Management, Vol. 84, 10234.

7. Khaskheli, A., Jiang, Y., Raza, S., Qureshi, M., Khan, K., Salam, J. (2020), "Do CSR activities increase organizational citizenship behavior among emploeyees? Mediating role of affective commitment and job satisfaction", Corporate social responsibility and Environmental Management, Vol. 27 No. 6, pp. 2941-2955.

8. Kim, H., Rhou, Y., Topcuoglu, E., Kim, Y.G. (2020), "Why hotel employees care about Corporate Social Responsibility (CSR): Using need satisfaction theory", International Journal of Hospitality Management, Vol. 87, 102505.

9. Meyer, J. Allen, N. (1997), Commitment at the Workplace: Theory, Research and Application", SAGE Publications.

10. Nazir, O., Islam, J. U. I., Rahman, Z. (2021), „Effect of CSR participation on employee sense of purpose and experienced", Journal of Hospitality and Tourism Management, Vol. 46, pp.123-133.

11. Privredna komora Srbije (2020), "Osnovni ekonomski pokazatelji privrede Srbije za period 2015-2019.", available at: https://pks.rs/strana/makroekonomski-indikatori (12 March 2021)

12. Republika Srbija Republički zavod za statistiku (2020), "Trendovi, IV kvartal 2019.", available at: https://publikacije.stat.gov.rs/G2020/Pdf/G20208001.pdf (12 March 2021)

13. Su, L., Swanson, S. (2019), "Percieved corporate social responsibility impact on the wellbeing and supportive green behavior of hotel employees: The mediating role of the employee-corporate relationship", Tourism Management, Vol. 72, pp. 437-450.

14. Wang, C., Hu, R., Zhang, T. (2020), "CSR in international hotel chains and its effects onlocal employees: Scale development and empirical testing in China", International Journal of Hospitality Management, Vol. 90 No. 4, pp. 1-14.

15. Yasir, M., Majid, A., Yasir, M., Qudratullah, H., Ullah, R., Khattak, A. (2020), "Participation of hotel managers in CSR activities in developing countries: A defining role of CSR orientation, CSR competences and CSR commitment", Corporate social responsibility and Environmental Management, Vol. 28 No. 1, pp. 239-250.

16. Youn, H., Lee, K., Lee, S. (2018), "Effects of corporate social responsibility on employees in the casino industry", Tourism Management, Vol. 68, pp.328-335.

\section{About the authors}

Milena Damnjanović, born Stanisavljević, MSc, a Ph.D. student of Economics at the Faculty of Economics University of Kragujevac, Serbia, and teaching assistant for the field of Entrepreneurial and Business economy at the Faculty of Technical Sciences in Čačak, University of Kragujevac, Serbia. The main field of interest: corporate social responsibility, organization, entrepreneurial economy. Milena is the author of approximately 25 scientific papers published in journals and conference proceedings. The author can be contacted at milena.damnjanovic@ftn.kg.ac.rs 